\title{
Engines at top speed! Using the adventures of a comic book motorsports hero as an approach to understanding recent French history
}

\author{
Sébastien Laffage-Cosnier ${ }^{\mathrm{a}}$, Noemi García-Arjona ${ }^{\mathrm{b}}$ and Christian Vivier ${ }^{\mathrm{a}}$ \\ ${ }^{a} U$-Sports Besançon, University of Franche-Comté, Besançon, France; 'b UFR STAPS Rennes, \\ University of Rennes 2, Rennes, France
}

\begin{abstract}
Jean Graton created a series of comic books called Michel Vaillant, and its motorsports hero bore the same name. Michel Vaillant made his first appearance in 1957 in the weekly Tintin. Young French boys who loved adventure, sports and car racing greeted this publication with great enthusiasm. We studied the first series of Michel Vaillant, composed of 16 comic books produced in the 1960s. We have departed from traditional approaches and have based our method on the analysis of the sources of Graton's inspiration. We link these sources to the comics' text bubbles, visual signs and iconic meanings of the drawings. Our analysis of the comics' iconography based on the establishment of a mass culture dedicated to the automobile brings to light the existence of an urge to go beyond the limits of tradition. Our research highlights that the success of Michel Vaillant is due, in the main, to the series' detailed knowledge of the automobile sports industry, and to the myths of speed, youth and progress that it promulgates - myths in which its young male readers could see themselves reflected and which would also prepare them for the future.
\end{abstract}

\section{Introduction}

In 2002, the Sport \& Comics Exhibition was held at the International Festival of Comics in Angoulême, France: the Ninth Art had included sport. ${ }^{1}$ Some time after this, university studies were published which analysed the representation of sport in the most well-known comic books. Thus, the sport comic hero Alf Tupper ${ }^{2}$ and a series recounting the adventures of an athlete during the Second World $\mathrm{War}^{3}$ were studied and the theme of the Olympic Games was analysed in illustrated anthological series such as Bibi Fricotin, Les Pieds Nickelés, Asterix and The Smurfs. ${ }^{4}$

The comic book character Michel Vaillant, created by Jean Graton, appeared for the first time in 1957 in the weekly Tintin. The character was

CONTACT Sébastien Laffage-Cosnier sebastien.laffage-cosnier@ubfc.fr @ Culture, Sport, Health and Society Research Laboratory (C3S, EA 4660), U-Sports Besançon, University of Franche-Comté, France (c) 2017 The British Society of Sports History 
well received and this led to the creation of the series Michel Vaillant; some episodes appeared in Tintin every week. After the conclusion of each story, all of the episodes were published in one album, and when the first album, Le grand défi (The Big Challenge), appeared in 1959, young French boys, enthusiasts of adventure sports and racing, became fans overnight. This series has been translated into 15 languages and, as evidenced by Peter Dron writing in The Telegraph in 2004, Michel Vaillant achieved an international reputation. ${ }^{5}$ Since the late 1950s, 71 albums and around 20 million copies have been sold. ${ }^{6}$ This series remains one of the most popular comics in France, and has been published in 16 countries, including Japan and the United States. Even in 2015, according to the monthly cultural magazine Les Inrockuptibles, Michel Vaillant, and in particular the volume Le pilote sans visage (The Faceless Driver), was among the 150 best historical adventure comics. $^{7}$

The popularity and status of this comic character raises a number of questions. Exactly what messages did this series convey to its young readers? What was its impact on them and what social role did it play in their lives? What were the values held by Jean Graton? What were the sporting events in which Michel Vaillant participated? How and in what ways did this series integrate the automobile world of that time? In other words, did the Michel Vaillant series preserve tradition or was it a powerful driver of the change stimulated by the automobile industry and its key innovations? To answer these questions, we studied the first 16 albums of Michel Vaillant, from no. 1, Le grand défi, released in 1959, to no. 16, Km 357, released in 1969.

The Michel Vaillant comic book series, conceived and illustrated by Jean Graton, preserved the traditional representations of the bourgeoisie. The first 16 albums faithfully portray the values and the social roots of upbringing of the 1960s, i.e. those of the importance of work and efficiency, family spirit, confidence in one's closest friends, patriotism and the glory of the French flag. However, our analysis of the series' iconography highlights both the establishment of a mass culture focused on automobiles and the desire to break with tradition. In the end, the victories of Michel Vaillant made modernity visible and, by means of the car, a revered and symbolic object, brought young people, especially males, to the threshold of the world that was waiting for them when they left childhood and adolescence behind. In addition, the car races in which Michel Vaillant competed demonstrated the ruthless economic 'war' fought among the great nations and global companies during the second half of the twentieth century. The victories of this comic book hero were projections of a favourable outcome from this conflict. The success of Michel Vaillant became a modern myth, according to Roland Barthes' analysis ${ }^{8}$ myths that reassured a generation who were concerned about their future and their participation in a liberal society driven by competitiveness, production and profit. 
Our method of analysis puts the sources in their context of creation and distribution, thus preventing them from being categorised as marks of reality. In our exploration, we examine both the creator of this comic book series and its uncommon trajectory. ${ }^{9}$ Even though we agree with Thierry Groensteen when he affirms that 'the comic is dominantly visual literature, ${ }^{10}$ the fact remains that 'the comic is primarily a tale, ${ }^{11}$ told to a particular reader - and this is the methodological approach to the corpus that we used. ${ }^{12} \mathrm{We}$ accept that historical narratives have many different modes of expression. ${ }^{13}$ We agree with Day and Vramplew's recent article on revisiting methodologies employed for the history of sport and the use of comic as a fictive or literary source, 'given its power as a cultural force in shaping people's understanding of their world'. 14

Our study for depicting an important period of recent French history is thus unconventional, in that we base it on a fictitious sport hero. Our approach is mixed. On the one hand, the storytelling presented in this paper is qualitative, but we also include a quantitative analysis. As Vamplew states, ${ }^{15}$ despite the traditional rejection of the use of statistics in sport history, numbers can help the historian to better clarify the results, as we attempt to show with our cross-analysis of the 10 years of comic albums of Michel Vaillant's adventures described here. On the other hand, our inquiry relies on content and visual analysis; we address semiological and iconographical assumptions, thus agreeing with Huggins that visual examination gives a broader dimension. ${ }^{16}$

Unquestionably, the comic book is 'drawn literature' ${ }^{\text {'17 }}$ and, as such, it should be analysed using 'the drawing and the text [which] weave together many links'. ${ }^{18}$ Thierry Groensteen uses the notion of 'iconic solidarity', ${ }^{19}$ wherein the texts in the comments are interpreted, compared with plastic signs and with iconic and iconographic meanings. As 'the story does not privilege only text' and 'the picture does not just illustrate, ${ }^{20}$ each box was assigned a category that indicates this cross-analysis. We repeated this for each comic box. Our mixed approach is based on Roland Barthes' theories, ${ }^{21}$ which state that the visual fills in verbal language and even that all systems of signs can supplement verbal language. ${ }^{22}$ The semio-historic decoding of the first 16 albums in this series was carried out according to Barthes' system using five interpretative steps (documentary, linguistic, contextual, plastic and iconic analysis) that overlapped.

\section{Michel Vaillant, a comic that put youngsters at the wheel}

The success of Michel Vaillant was founded on several factors. On the one hand, the series used plots that were permeated by the atmosphere of modernity and development of the automobile. On the other hand, it appeared at a particular moment in the history of the Francophone comic, when one of its 
missions was educational in nature. However, interestingly, it was the singular life story of Jean Graton that added considerably to the fame and reputation of the series.

Jean Graton was born on 10 August 1923 in Nantes, France. ${ }^{23}$ His father, André Graton, was a motorcycle enthusiast. He was secretary of the Motorcyclist Club of Nantes and he organised races in the Nantes region. The great passion of the father led the son into the world of racing and speed. By the age of 12, Jean Graton was a regular attendee of the 24 Hours of Le Mans, ${ }^{24}$ the legendary racing event that marked the drawings and scripts of the Michel Vaillant series. ${ }^{25}$ Alongside the mechanical universe in which he was immersed, Graton had a significant talent for drawing and, given his environment, he drew mainly motorcycles and cars. ${ }^{26}$ His talent was recognised early on; at the age of 8 , he won a drawing competition sponsored by Le Soir, ${ }^{27}$ a major Belgian newspaper. ${ }^{28}$ This drawing, demonstrating the influence motorsport had on him, showed his father repairing his motorcycle in front of his garage. ${ }^{29}$ Graton grew up with a pencil in one hand and a wrench in the other: perfect conditions for becoming a widely-recognised motorsports illustrator.

As a young adult, Graton worked as a tool and die maker at the shipyards of Brittany. When he was 25 , he left Nantes to embark on a career in illustrating in Brussels. He was a motorcyclist, and was an enthusiast of motorsport and sport in general (tennis, rugby, roller hockey). Graton was hired by the newspaper Les Sports as a cartoonist, for sport design and advertising. $\mathrm{He}$ worked with the publisher of Spirou, a Belgian periodical, where JeanMichel Chartier entrusted him with the first illustrations for Uncle Paul, and then, in 1953, he started working for a competitor, the weekly Tintin, ${ }^{30}$ created by Raymond Leblanc and Georges Dargaud five years before. He stated in an interview during the illustrating of Tintin: 'Sport has always fascinated me. ${ }^{31}$

Tintin featured mechanical innovation and had special issues such as Aviation and Auto. ${ }^{32}$ It had great success in France, and sold between $100,000^{33}$ and 350,000 copies $^{34}$ in this period. It was read by mainly middle-class children aged between 5 and 16 years. Like all young illustrators starting out, Graton began with complete stories on four full pages. ${ }^{35}$ As of no. 250 in 1953, Graton's presence could be seen on the covers of Tintin, which announced his complete stories. His drawings showed sports scenes such as automobile ${ }^{36}$ and, obviously, motorcycle races, ${ }^{37}$ but also cycling, ${ }^{38}$ basketball, ${ }^{39}$ boxing, ${ }^{40}$ ice hockey, ${ }^{41}$ rugby, ${ }^{42}$ American football ${ }^{43}$ and even sailing. ${ }^{44}$ Soon, following all these drawings and stories, Graton took on a major role at Tintin.

In 1957, in no. 433 of 7 February of the French edition, Jean Graton signed his first short story 'Bon sang ne peut mentir' (Blood Will Out) where Michel Vaillant participated in the Monte-Carlo Rally. ${ }^{45}$ Published at the rate of two strips per week, these short stories were a test to see whether the hero would 
be accepted by Tintin's readers. Success was rapid and issue after issue sold out. ${ }^{46}$ This success was not a coincidence. From the very beginning, Tintin had been published by the clergy, including the Jesuits, ${ }^{47}$ who published several illustrated magazines for children. Tintin gained instant respect from parents concerned with their children's education: the clergy supported Tintin, and the layout of the weekly respected the format of educational materials. Their children were reading happily and they could rest assured that the educational quality was high. Here, we introduce our first quantitative analysis. Although he created an original car story, Graton respected Tintin's editorial policy by using geometric standards, or the classic 'waffle' mode, of placing its strips in twelve boxes, although our study shows that the average number of boxes per page decreased over the 10 years of our study period of the Michel Vaillant albums. In no. 13, entitled Concerto pour Pilotes (1968) (Concerto for Drivers), the average number of boxes per page was reduced to seven followed by a slight increase in the following issues (Figure 1).

During this period, Graton was gradually deconstructing the 'waffle' style, and sometimes he followed a more modern, free-graphic style. Graton accommodated a new trend, ${ }^{48}$ which favoured freer breakdowns but emphasised the drawing and reduced the number of boxes per page; the last strip of album 16 consists of only three or four boxes per full page. ${ }^{49}$ By the second half of the 1960s, he had changed the geometric grid of his strips and produced a more flexible and lively presentation. This change in the architectural configuration of the boxes by strip is obvious in no. 11 Suspense à Indianapolis (Suspense in

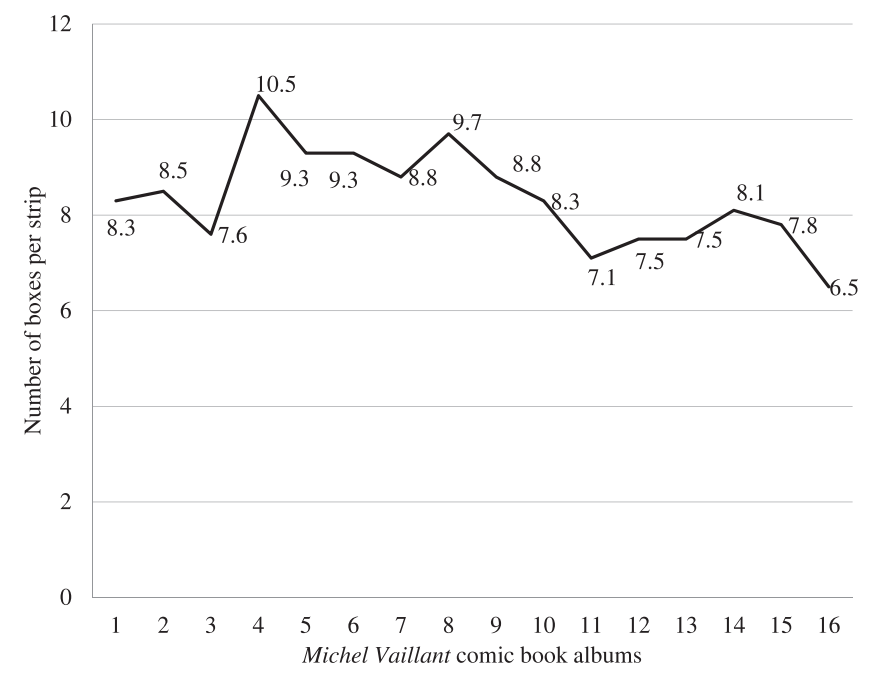

Figure 1. Evolution of the average of boxes per strip in the first 16 albums of the Michel Vaillant series (1959-1969). 
Indianapolis) released in 1966, where the average number of boxes per page falls below eight; this may suggest that Graton was trying to give more space to the drawing.

Some statistics regarding the weekly publication of Tintin might help explain these figures. The target readership for Tintin was middle-class children aged between five and 15 years. Tintin mostly depicted male heroes, ${ }^{50}$ therefore appearing to be primarily aimed at young boys. However, it should not be assumed that girls did not read it. Indeed, girls wrote to the weekly, just as the boys did, and the letters they sent showed both their interest in comics, as well as their frustration with stories centred mainly on the masculine universe. ${ }^{51}$ Yet in the late 1950 s and early 1960s, the comic did not get good press from the petty and middle bourgeoisie. If the stories could be drawn and presented to look like 'real academic books', they would gain immediate approval from parents. Jean Graton skilfully adapted his work to these demands. The text is a perfect fit and a pertinent indicator for making the comic book look educational. This interpretation helps to explain the quantity of sentences and words in the series of boxes. Because he was aware that parents were concerned that their children should both read and be educated by the comics, Graton remained faithful to the text and had no desire to depart from this principle. He maintained the same educational purposes, then, for the Michel Vaillant series, which Tintin had always respected. The French driver's adventures were the opportunity to encourage young children to love reading, and, even more, to impart knowledge and know-how, thus ensuring the development of a general culture.

Graton's major achievement was that he managed to link form and content. While the standards for architecture and placement of the text were reassuring for parents, the content of Michel Vaillant was nonetheless instructive for young readers who were immersed in the reality of modern mechanics. A great connoisseur of sports and the universe of the automobile, Graton made Michel Vaillant as realistic as possible and he noted that he was careful to be 'well documented for building the story'. ${ }^{52}$ His distinctive drawings leave an impression of stiffness, but being a virtuoso of the clear line style (a well-known style promoted by Hergé, using clear, strong lines, all of the same width and no hatching ${ }^{53}$ ), he specifically highlighted the curves of his vehicles so that young readers could immediately recognise the most common models from the most prestigious manufacturers.

Graton's boxes are real showcases by which the boys could explore racetrack maps, the historical and technical intricacies of a race and even the monuments of the cities that the hero visited. The reader was treated as a spectator, or rather, a viewer following a race, but this spectator did not just sit in the stands - he was a real participator in all the aspects of a race. To make this as realistic as possible, Graton carefully documented his work with newspaper articles, photographs and interviews. He knew 'all the race 
tracks, routes, and garages where Michel and his friends could be found' and devoured 'all the literature that was published on the automobile'. ${ }^{54}$ Graton was a motorsport reporter who immersed himself in the milieu. He was also the kind of illustrator and author who, to write Route de nuit (Night Route), did the whole Paris-Marseille route aboard a truck himself, so that he could gather enough documentation to recreate an authentic atmosphere for his readers. ${ }^{55}$ By creating Michel Vaillant, Jean Graton was using his first-hand experiences of the world of motor racing - first to document it, and then to integrate real drivers' experiences into his comic book stories.

In the end, from reality to representation, the adventures shown in his albums revealed what motorsport meant to the eyes of a connoisseur artist. Graton did not, however, content himself with merely reproducing the enthusiasm of the period for car racing and for the French automobile. He went beyond the realm of sports and strove to educate his readers about motorsport and its economic challenges. This model prepared his youthful readers for the changes and modernity of the 1960s.

\section{Motorsports, the car industry and innovation}

The development of the sports automotive industry and its influence are constants throughout Michel Vaillant. The industry became a symbol for a historical period in France, which was profoundly marked by a sharp rise in economic development. During the 10 years we analysed for our study, the car symbolised the increase in spending power of the middle class, the rise in mass consumption and, also, a way to indicate social position. This situation was transferred to an international scale, since the French and European car industries were confronted by the New World - the industrial hegemony of the United States - as was evidenced in the main argument in Le grand défi. The historical context was that of the Trente Glorieuses (The Thirty Glorious Years) - the 30-year post World War II boom, which lasted until the economic crisis of the 1970s. During this time, France, while encountering some difficulties, reached its highest peaks of dynamism, investment and expansion. ${ }^{56}$

Our detailed study of each box of the first 16 albums of the Michel Vaillant series covers all of the 1960s, giving an overview of the major recurring themes. Our qualitative analysis enabled us to further define these major trends. We used the system of categorisation as explained earlier, which gave us 'the possibility to transcode into words a perceived thing. ${ }^{57}$ We systematically carried out this procedure for the 8,211 boxes of the corpus. A total of 37 topics emerged, which were sorted into five main categories: (1) the representation of motorsports and car racing, (2) the cases where the car symbolised a product of consumption - we develop this category in detail later; (3) the presence of other non-motorised sports; (4) the family 


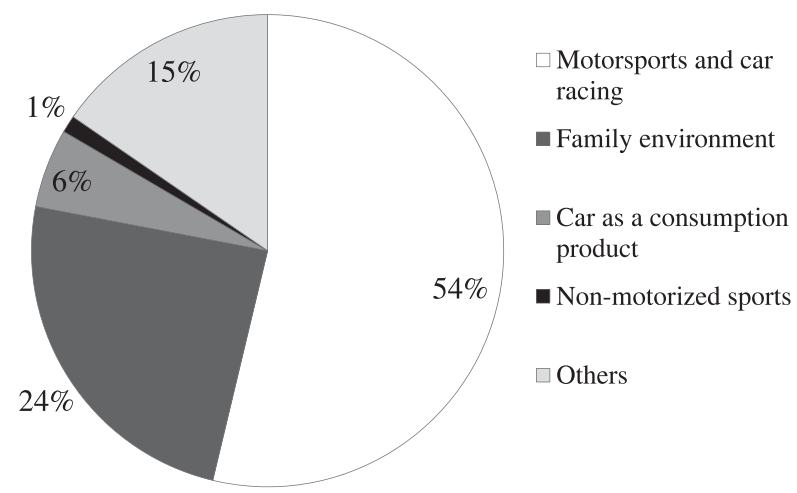

Figure 2. Main categories in Michel Vaillant.

context of the hero (the Vaillant family), and (5) a category called 'others', where we placed diverse topics drawn from motorsports or car industry topics, such as political issues. As shown in Figure 2, the category 'motorsports and car racing' is the largest of this series, followed by 'family environment', due to the fact that the car company was managed by the Vaillant family and that every member played a crucial role in the plots. In the third main category, there are the topics related to the car industry, and how the automobile became a product of mass consumption.

A comparison of the five categories throughout the 16 volumes (Figure 3) shows that the plots involving 'motorsports and car racing' dominate most of the 1960s, followed by Vaillant's 'family environment'. The car as a product of consumption remains constant throughout the years, but always in a secondary position. Only in the albums when the plot is not centred on racing do other topics, such as political issues, dominate the plots.

The adventures of the race car driver Michel Vaillant clearly reflect the new economic and social period, particularly evident in the emergence of a major economy, i.e. the car industry in France. The driver and his teammates won every race when the French firms were proceeding full steam ahead, such as Renault with its Caravelle model, Simca with the Versailles model and the famous Citroën DS.

There were many similarities between the Michel Vaillant series and some of the real French car manufacturers, i.e. the companies were both a family and a traditional business. This was the case, for example, for the Peugeot and Michelin firms. Renault was also a model to follow and one of the most exported images of France. The government policy of the Fifth Plan (1966-1970) aimed at facilitating 'the creation or the development of firms with French capital, and with international contacts: they are the only ones capable of carrying forward the efforts of investment, research and market penetration required to compete internationally. ${ }^{58}$ The Michel Vaillant 
(a) 450

(b)
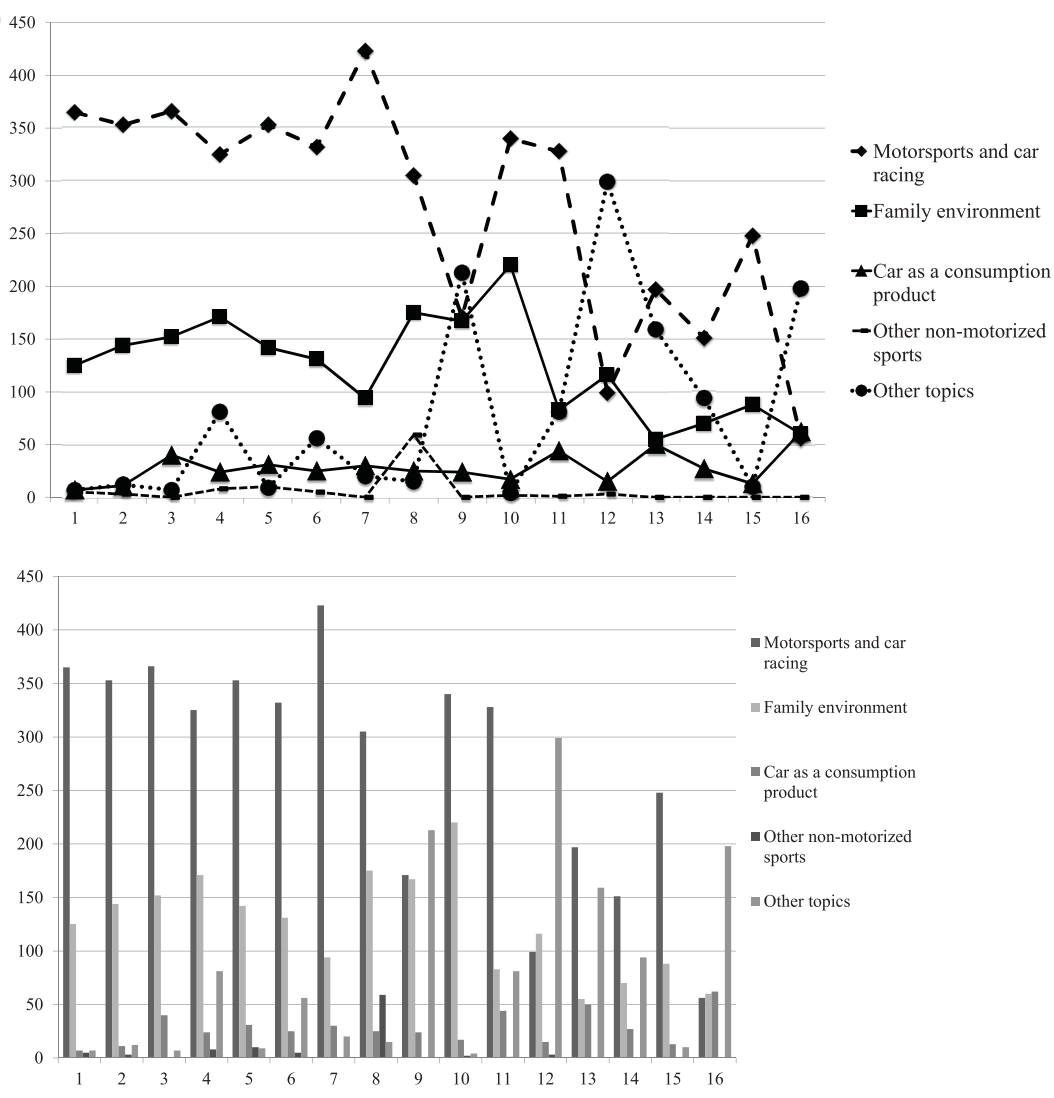

Figure 3. Main categories in Vaillant throughout the corpus (1959-1969).

comic books clearly reflected the competitive dynamics in the French sports car industry. The most recurrent representation of this was the rivalry between the American race car driver Steve Warson and the French driver Michel Vaillant, which reflected the actual rivalry between the car industries on either side of the Atlantic, as well as the opposition of two different cultures - the new and the old world. In addition, Graton wanted to show how wellprepared and efficient the French industry could be against the American economy. As Pascal Lefèvre wrote:

It is mostly in the context of the Cold War that this sports comic affirms the special place and identity of a Europe that needs to unite if it wants to compete with the USA and the USSR. This Michel Vaillant comic seems to be the only explicit example of such an idea in a French or Belgium comic up to $1970 .{ }^{59}$

The storyline of Le grand défi set out the meanings and aspirations. With the ruthless economic struggles at the heart of the automotive industry as the background, the human values demonstrated by the champion Michel 
Vaillant and his success were intended to reassure the French public, especially its youth, about French superiority in all aspects of the car industry (for example, production, creativity and innovation, performance and reliability of vehicles, and prices), at a time when the globalisation of markets was on the rise. The album is remarkable: the two rivals, Steve Warson and Michel Vaillant, gradually learn to know, respect and appreciate each other during the races. Everything is said in the epilogue (p. 64). Both drivers have become the greatest of friends and yet they do not share the same values! Actions speak for themselves. Michel refuses the racing cup for 'The World's Best Driver' because he says that Steve could not show his talent and compete as best as he could against him because of a 'stupid accident'. The message delivered by Jean Graton is clear: friendship and the traditional values of honour, respect and loyalty, are more important than victory. In addition, when Michel sees Steve in the hospital, he learns that his very own family prevented Steve's family from visiting him. Steve is alone in the hospital. Michel arranges for Steve's family to be looked after. Both drivers become inseparable. It was as if the French business model, in which the family played a significant role, gave a clear demonstration of its strength and humanity against the American model, based primarily on profit. This lesson seemed to indicate that if France, and especially French youth, were imbued with such values, then neither one nor the other could miss out on the economic opportunities available. Included in this message was the fact that the French would be well prepared to conquer the American market.

The idea of significant investment in cutting-edge research, innovation and reliability in order to compete internationally was broadly reflected in Michel Vaillant. The first example of this appeared in Le 13 est au départ (Number 13 is at the Starting Position), ${ }^{60}$ where the Vaillant car company was developing brand new ideas and prototypes to improve their cars (Figure 4). During this period, the car was enhanced by its technical qualities and its aesthetic value.

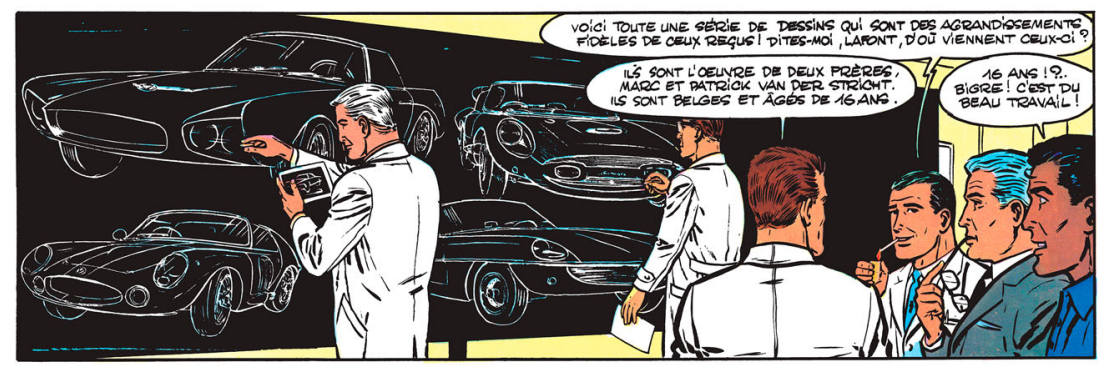

Figure 4. Source: Jean Graton, Le 13 est au départ, no. 5 (Bruxelles: Graton Editeurs, 1963 [edition 2010]), 11, ๔ Jean Graton/Graton-Dupuis Publishing, 2017. 
For manufacturers, it was no longer only a question of producing in quantity to respond to the greater demand, but also to offer extremely attractive vehicles. Throughout this period, innovations abounded and French cars were famous for these, particularly Citroën: improved road handling in general, and front-wheel drive, disk brakes and hydropneumatic suspension were rapidly implemented in domestic models, particularly in lower- and middle-priced vehicles. Later on, they were developed for (and admired by) foreign firm models. At the beginning of the 1960s, several French models symbolised a mix of the best innovations, combined with comfort, price, aesthetics and performance. ${ }^{61}$ In the Period of Reconstruction, after the Second World War, a general trend of globalisation of the car industry emerged, including new modes of production and assembly, innovation, and new competitors such as the Japanese car industry, which began in the 1960s and 1970s. To deal with this situation, the French car industry had to be competitive, effective, and innovative.

Another example in Michel Vaillant shows how the Vaillant family company had to deal with industrial espionage; ${ }^{62}$ Graton wanted to put the spotlight on how fast the French firms were growing at the European and global level, and how closely their innovations were being observed (and even spied upon) by foreign car manufacturers. The high technological level of French cars was tested against the reliability of German cars. ${ }^{63}$ Here, he echoed the real competition between the two countries in the motor industry. The German industry was rapidly rebuilt after the Second World War. Their car production tripled from 1950 to 1955, moving from 216,000 to 690,000 units. Although their domestic market was not saturated, they followed the same strategy as the French firms and nearly half of their cars were exported to foreign markets. ${ }^{64}$

All the technological innovations developed and tested in racing cars were quickly implemented in normal vehicles, thus bringing the opportunity to 'Mr. Average' to enjoy the cutting-edge technical improvements in their own cars. During this period, the car ceased to be a symbol of privilege and, instead, it became a product accessible to the middle class. In this case, we can say the car is one of the most powerful symbols of democratisation. Advertising cars specifically to the working class, increased financial credit and loans and the economic growth of the Thirty Glorious Years in France motivated the working class to buy cars, as we will see next.

\section{Inside the democratisation process: motorsport events and cars for all}

In Le huitième pilote (The Eighth Driver), published in 1965, Graton provided a magnificent illustration of the process of the democratisation of car acquisition as the Vaillante 1200 model was being produced. Michel Vaillant had to 
face the Executive Board of his company and defend the idea of lowering the price by $5 \%$ in order to make it more accessible to the people.

The democratisation of the car was also linked to the civilisation of leisure or the 'cultural revolution of free time' as expressed by Dumazedier; ${ }^{65}$ this also brought with it an increased diversification of sports modalities and broader social access to sports practice. As a summary of the situation: 'For millions of French people, the car is more than a means of transport: it opens the road to vacation and provides access to the civilization of leisure. ${ }^{66}$ The song by Charles Trenet, first sung in 1950, entitled Route Nationale 7 (Route 7) and, even better, the satirical film, Trafic (Traffic), by Jacques Tati, are two more illustrations of this. Another important factor emerged in the 1960s a new, powerful and highly consumerist market segment: the generation of young people. The pop culture generation was seduced by massive industrial and commercial offers, responding to the desire for eternal life, youth and modernity. The car companies, with examples in the French context such as Simca or Matra, were part of this. ${ }^{67}$

Media democratisation and the effects of a more visual society were also present in Michel Vaillant. The media were generally present throughout the series. This observation is not surprising given the spectacular nature of motorsport and the enthusiasm it provoked from the crowds. During the period under study (the 1960s), not one album escaped from media treatment; it was missing in only a few issues where the intrigue and action took place outside the world of motor racing. ${ }^{68}$ Moreover, journalists, reporters, photographers and cameramen were systematically present on the racetracks and routes and during the trophy presentations. Only a few albums (three out of the 16 studied) do not show journalists interested in racing car drivers. That Graton understood the association between the automobile and the media is obvious in the modernity of his work and perhaps explains its continuing popularity.

We provide here three main media examples. First, the references to the cinema are significant. We have identified two very different uses. On the one hand, because of a film he saw, taken by an amateur photographer, Vaillant was able to gather technical and strategic information about his opponents. ${ }^{69}$ Here, Graton showed the importance of observation and the capacities for analysis of rival drivers at high-level competitions. On the other hand, this time involving the Seventh Art, Michel Vaillant was recruited to be the stunt double of the lead actor of a Pathé film production for rough racing scenes and dangerous stunts (Figure 5). ${ }^{70}$ The film, entitled Les Cassecou (The Daredevils), tells a racing story that has hopes of becoming a 'breathtaking' movie - as the tagline of the film declares. ${ }^{71}$ In 1964, Graton's idea to associate car races and cinema was premonitory. In the album of Les Cassecou, Michel Vaillant was immersed in the world of cinema, and in 1971, it was Steve McQueen's turn to star as a race car driver in both the famous 

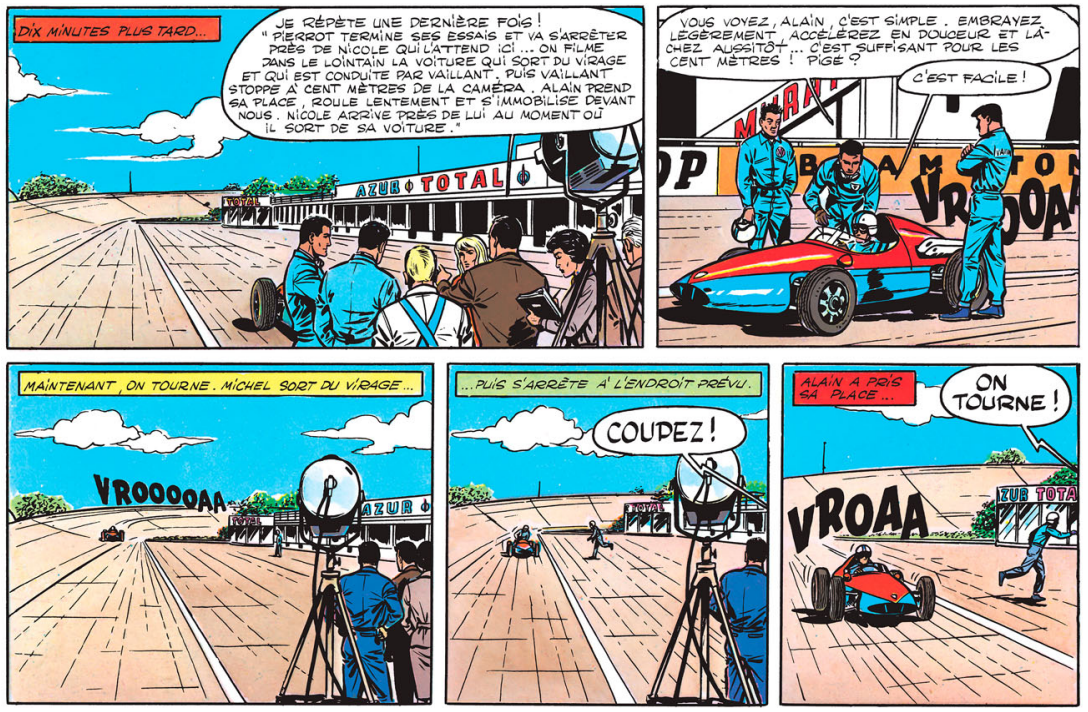

Figure 5. Source: Jean Graton, Les casse-cou, no. 7 (Bruxelles: Graton Editeurs, 1964 [edition 2010]), 26, (c) Jean Graton/Graton-Dupuis Publishing, 2017.

movie Le Mans by Lee H. Katzin, and in On Any Sunday: Challenge One by Bruce Brown. In 1972, Jackie Stewart took the wheel in Weekend Of A Champion by Roman Polanski and Frank Simon. These films, like the comic Michel Vaillant, associate youth, speed and challenge. ${ }^{72}$

Secondly, television made its appearance in the Michel Vaillant series. It made a grand entrance with six boxes showing broadcasts of interviews with champions. $^{73}$ The reader suddenly becomes the viewer, watching Michel Vaillant as he was interviewed, in black and white, after his victory (very symbolic) over the Americans in Indianapolis. ${ }^{74}$ The issues that followed continued to feature TV. In 1963, in the fifth album, ${ }^{75}$ Vaillant's mother watched her son's exploits on the small screen in black and white at a time when car races were rarely broadcast. In album no. 10, an interview with Michel Vaillant was broadcast in six boxes, ${ }^{76}$ and the Vaillant family learnt about his world record for land speed $(1250 \mathrm{~km} / \mathrm{h})$ thanks to a colour television news broadcast. ${ }^{77}$ The increasing presence of motorsports events on TV made the sports myths of speed and youth more accessible to all; Michel Vaillant became part of this through his victories and the representations of sports champions (Figure 6). ${ }^{78}$ As Loubet notes, 'What better way to maintain the dream [of The Thirty Glorious Years] and to forge a legend than through successes in sport?. ${ }^{79}$ The celebration of speed was represented in Michel Vaillant, but it was also real, as in 1956 when Renault and its Etoile filante model (Shooting Star) made a new world speed record with $309 \mathrm{~km} / \mathrm{h}$. 


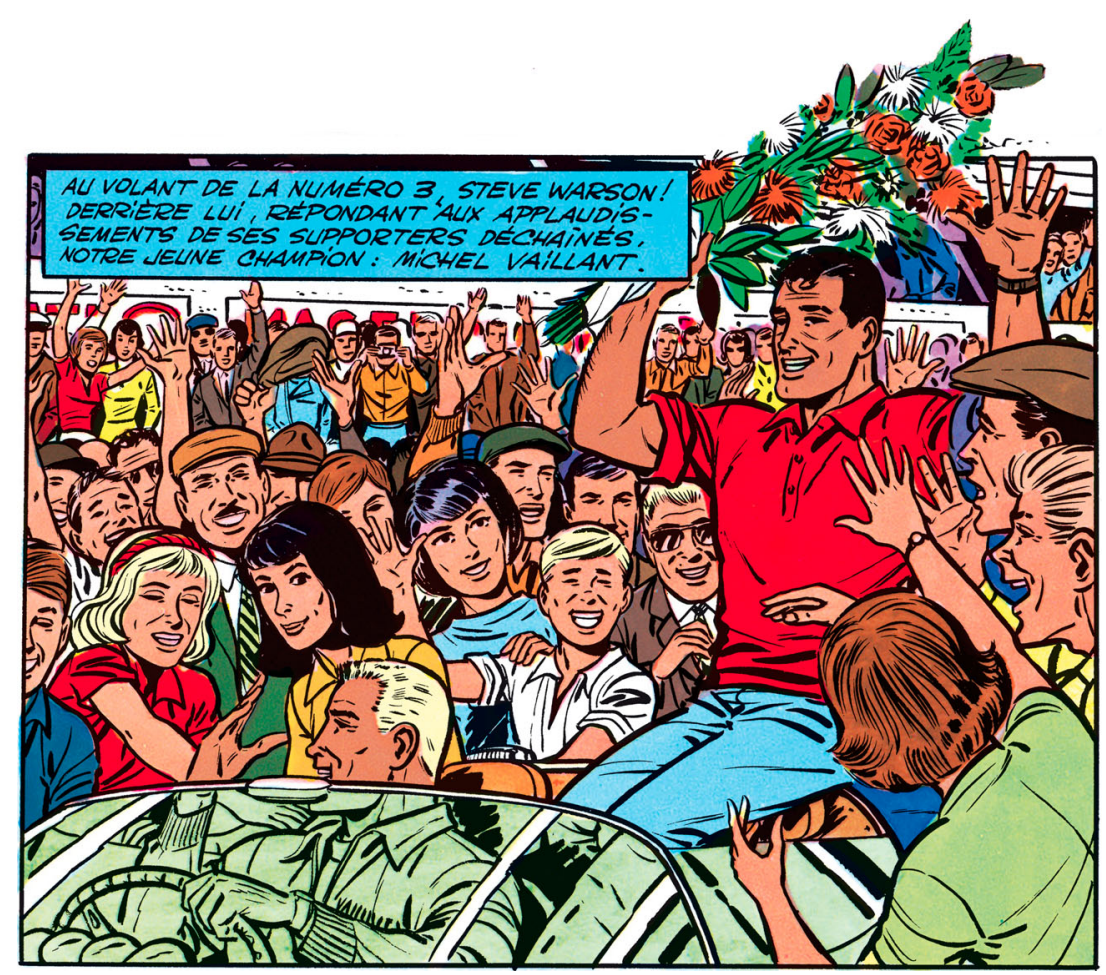

Figure 6. Source: Jean Graton, La trahison de Steve Warson, no. 6 (Bruxelles: Graton Editeurs, 1964 [edition 2010]), 3, ๔ Jean Graton/Graton-Dupuis Publishing, 2017.

Besides television and the cinema, a third media focused on car innovations and attracting consumers: the press. It is widely represented in the Vaillant series, often in the first pages of each album, when the daily newspapers present the plot. The second strip of the first album of the series is the best illustration of this. ${ }^{80}$ The manager of the great daily L'Eclair de France, surrounded by his editorial team, invited the whole Vaillant family to the newspaper's headquarters. He then explained to them about the race that he, and his US counterpart of the New Indian, had created to see who would be 'The World's Best Racing Car Driver'. In addition, Graton uses the press to create suspense in storylines, which served to enliven the Vaillant family's dialogue as they discussed the headlines or breaking news. ${ }^{81}$ The largest French daily sports newspaper L'Equipe was represented ${ }^{82}$ and other national newspapers with a wide circulation such as Le Figaro, France-Soir, Paris-Presse, L'Eclair-Sport ${ }^{83}$ and even American publications such as CarsSports ${ }^{84}$ Houston Sport and the Kansas News. ${ }^{85}$ All Vaillant's car racing achievements, results, victories and even problems, served up by tabloids such as Le Rapporteur - L'hebdomadaire parisien qui ne cache rien (The 
Reporter: The Parisian Weekly that Reveals Everything!), ${ }^{86}$ were featured in the press. All the variations of the media were there: regional, national and foreign press, national and foreign sports magazines, weekly tabloids announcing all the scandals, just as in real life, where the specialist press, such as L'AutoJournal, already existed. Founded in 1950, the sales figures for this French magazine were extraordinarily high; ${ }^{87}$ an annoyance for some French firms, because it published critical reviews and technical scoops about new models.

Thus, the mass media was omnipresent in the Michel Vaillant series, showing the ties that existed between motorsport and the press, television, films and even radio, such as the famous programme that had the same name as album no. 4, Route de nuit (1962). And most of all, all of this showed that Jean Graton had perfectly captured the two myths of the contemporary world: those of the media and speed.

\section{Modern myths promoted by the Michel Vaillant comic books}

The iconological analysis that we used to analyse the Michel Vaillant series revealed a number of interesting topics. We implemented Panofsky's approach, ${ }^{88}$ which enables the identification of the original contextual symbolic meanings that influence and determine the value of the subject under study. ${ }^{89}$ We thus identified the connotations that conveyed the deep meaning of each of the images. We started with a comparison with other creations of the same period, linking them to an artistic movement, to a class or group in a given context or to the mentality, values, allegories, myths and representations rooted in the collective imagination of France.

Our results enabled us to identify three main categories in this imagined world of motorsports. First, the 'bagnole' (French slang for car) is a strong 'material' symbol that marks the generation of the 1960s, immersed in, and perhaps submerged by, the consumer society. Michel Vaillant, then, can be seen as the hero who is fighting for the freedom of mankind, confronted with the material limits of movement and transport in a society whose leitmotif is mobility. He embodies the young male population's dreams of fast travel and intense experience. This is evidenced from the very first issue, where the young reader is invited to sit at the wheel of a dream car, ${ }^{90}$ to be a co-driver in a Michel Vaillant rally in the Carrera Panamericana, ${ }^{91}$ or to try to break the sound barrier with the dragster Sonic Bird alongside Steve Warson. ${ }^{92}$ Michel Vaillant and his exploits enable young readers to explore the bourgeois universe of speed and racing cars and to live it in their vivid imagination. In addition, the creation of a 'popular' car (one that was affordable for many) - the Vaillante 1200 model - in album 8 gave access to freedom of movement for this French generation: a sign of the process of speed democratisation. ${ }^{93}$

Secondly, by extolling speed, the Michel Vaillant series created a living myth. Our plastic analysis corroborates this observation. The 'speed lines' 
and onomatopoeia (such as Vroooommm and Wrooooaaaaaaw) fill the drawings, as on the cover of album $11^{94}$ or in the boxes from the next album on page $64 .{ }^{95}$ The influence of slow motion on TV (used for the first time in the US in 1963 during an American football match broadcast by CBS and in France in 1965 during the Football World Cup qualifying matches) is evidenced in the illustrated chrono-decomposition of movement in album $10 .{ }^{96}$ The male-only fascination with big engines, induced when the Formula 1 organisers were searching for acceptable rules (the limitation of the cylinder capacity of atmospheric and compressed engines) was another factor inherent in the worship of speed. ${ }^{97}$ Our linguistic and iconic analysis of the 16 issues highlights the increase in speed capacity of motorised vehicles. These range from endurance racing, where cars approach an average speed of $150 \mathrm{~km} / \mathrm{h}$ in Indianapolis in the first album in 1959, until the mythical breaking of the sound barrier with the Sonic Bird in album 14 in 1968 with a speed record of $1200 \mathrm{~km} / \mathrm{h}$. Subjects include Grand Tourer cars for rally races, Formula 1 or even the jet aircraft, Thunderbird, and Michel Vaillant seemed caught in this motorised frenzy to go ever faster. He was the incarnation of the myth of speed of the 1960s. ${ }^{98}$

Finally, the end of the 1960s brought with it the end of the belief in the perpetual progress of man and the concomitant symbolism. A significant number of sport theorists, such as Mike McNamee, ${ }^{99}$ Hans Lenk ${ }^{100}$ and David J. Lunt ${ }^{101}$ have used the ancient myth of Prometheus to better understand sport. In the Michel Vaillant series, the modern myth of unbroken progress meets this ancient myth of Prometheus, as in album 16, ${ }^{102}$ when a character, Mr. Morin, faces the monstrous bulldozers used to build the motorway network and stops them by simply standing in front of them. There were a number of myths that resonated and spoke to the readers of that time: the myth that mankind can hardly stop the steadily-perfected, fast, and powerful machines that he has made for decades and that they may end up harming him, and also that of the classic struggle between Ancient and Modern, between tradition and modernity. While, from one album to another, car gears spin at ever-higher speeds, it would seem that, in no. 16, the limits are reached. Michel Vaillant found himself obliged to accept his limits or, in other words, to adjust to driving a vehicle which, itself, could go no faster, having reached its own limits. In other words, the caricatured evolution of the speed of motorised vehicles driven by Michel Vaillant cannot be summed up simply by the study of the mobility, and the speed thereof, of things or individuals. The history of mobility demands a reflection upon the subtle relationship between the effects of motorised transportation and the results that the concomitant changes brought about. In short, the benefits of mobility for those who are transported contrast with the many and painful physical, ecological and moral transformations that this mobility imposed on other forces, be they human or mechanical. ${ }^{103}$ 
The historical analysis of the Michel Vaillant series is an opportunity to better understand the modern myths that were created when concerns and social fears surfaced as France entered a new economic era marked by a seemingly non-stoppable industry and international openness (the European Common Market and global competitiveness). As Roland Barthes pointed out, ${ }^{104}$ and we paraphrase: these contemporary mythological shapings reassured young males that they would be able to participate successfully in a new economic world.

\section{Conclusion}

Using the adventures of Michel Vaillant, a fictive racing car driver of the 1960s, we analysed a pivotal period of recent French history. Our aim was to study and interpret, from a semio-historic perspective, the iconographic representations of a sport hero of modern times, who rapidly became synonymous with the French sports car industry.

The relevance of the Michel Vaillant series is, first, based on its success and fame: it was one of the most widely-read and well-recognised comic book series in France. It was also approved by parents, due to its classic design, its welldocumented and realistic content about motorsports, its long texts in the bubbles and the reflection of traditional bourgeois values. At the same time, its young readers were its dedicated fans, eager to identify with their French star driver. Besides Graton's intention to reassure concerned parents about their children's reading, it is evident that the French sports legend represented modernity and innovation. During the 1960s, France reached a peak of economic dynamism and expansion, and the motorsports' industry was a clear reflection of this evolution. Moreover, Graton's ambition to pave the way for the arrival on the market of cars accessible to the working class - the affordable Vaillante 1200 model - underlines the importance of this icon of mass culture. A desired democratisation of both car acquisition and access to the great racing car events through the media (mainly TV and cinema) was omnipresent in the storylines. Nevertheless, inequality continued to exist, primarily because the car became a symbol of social distinction.

At the end of this semio-historical study, we observed three major levels of interpretation of Jean Graton's comics sport hero during the 1960s. First, the celebration of speed and the automobile; second, the existence of modern myths aimed at reassuring French youth, worried about a fast-approaching future marked by major economic changes and the opening of global markets; and, third, a necessary reflection on the relationship between modern motorised vehicles whose speed was exponential, and the effects this had on stationary objects. Also, from a philosophical and epistemological point of view regarding this third level of analysis, the following question can be posed: whether the external change, i.e. the increasing speed at which the 
human body could be transported, could bring about, at the same time, an internal change, i.e. an increase in the speed of mankind's evolutionary movement.

These three categories are inseparable. They overlap and are parts of a complex whole, which must be understood in its entirety. We attempted to access this by using an original approach based on Visual Studies. As proof, the important role that the stories of Michel Vaillant had in promulgating the passion for motorsports in youngsters can be seen in the example of the French professional driver Alain Prost. With four F1 World Championships, more than 100 victories during the 1980s and a mythical rivalry with Ayrton Senna to his credit, Prost confirmed the enormous influence that his readings of Michel Vaillant had had on his life: they led him to finding his vocation as a racing car driver. As he states in the preface of the first special collector's issue:

Michel Vaillant gave me a priceless gift: it introduced me to car racing. I will remain eternally grateful for this gift. I do not know if a teenager today can understand what Michel Vaillant represented to the people of my generation. Television rarely broadcast the Grand Prix: motorsport was a remote universe. I was twelve when Daniel, my elder brother, brought home a Michel Vaillant album. I remember it like it was yesterday. By reading, I was able to enter this mysterious world of motorsport, to discover all the ingredients: the cars, the men, the race tracks, the teams' strategies, the stakes, the intrigues. [...] It was not a simple comic series, but an incomparable piece of art where you could discover motorsport from the Inside - to be inside it and become part of Michel Vaillant's family. ${ }^{105}$

\section{Notes}

1. Bernard Fournier, ed., Sport \& BD (Issy-les-Moulineaux: L'Équipe, Olympic Museum of Lausanne, 2001).

2. Jeffrey Hill, 'I'll Run Him': Alf Tupper, Social Class and British Amateurism', Sport in History 26, no. 3 (2006): 502-19.

3. Sébastien Laffage-Cosnier, Jean-François Loudcher, and Christian Vivier, 'La guerre et ses représentations dans la Bande Dessinée: La destinée du héros sportif chez Pellos dans le journal Junior (1938-1940)', Modern \& Contemporary France 20, no. 3 (2012): 287-305.

4. Sébastien Laffage-Cosnier, Christian Vivier, and Michel Thiébaut, 'Les Jeux Olympiques célébrés par Bibi Fricotin, Les Pieds Nickelés, Astérix et Les Schtroumpfs', European Studies in Sports History 7 (2014): 197-221; Christian Vivier, Sébastien Laffage-Cosnier, Noemi García-Arjona, Teresa González Aja and Michel Thiébaut, ¿¿Estaba dopado el pitufo debilucho? Otra mirada sobre el atletismo olímpico de los años 80', Materiales para la Historia del Deporte 12 (2014): 41-51.

5. Peter Dron, 'The Largest Pilot of all Times', The Telegraph, 24 January 2004.

6. Sport.fr, 'Lettre de l'économie du sport, n ${ }^{\circ} 675$ ', 18 September 2003, http://www. sport.fr/automobile/michel-vaillant-un-tournage-au-coeur-des-24-heures-dumans-31122.shtm (accessed 11 October 2015). 
7. Jean-Baptiste Dupin, 'Les exploits de Michel Vaillant: Le Pilote sans visage, Jean Graton', Les Inrockuptibles, special no. 150 BD indispensables, August 2015, 28.

8. Roland Barthes, Mythologies (Paris: Seuil, 1954).

9. Benoit Peeters, 'A Never-Ending Trial: Hergé and the Second World War', Rethinking History 6, no. 3 (2002): 261-71.

10. Thierry Groensteen, La bande dessinée: mode d'emploi (Bruxelles: Les Impressions Nouvelles, 2007), 133.

11. Jean-Louis Tilleuil, Catherine Vanbraband and, Pierre Marlet, eds., Lectures de la bande dessinée: théorie, méthode, applications, bibliographie (Louvain-laNeuve: Academia, 1991), 46.

12. For a formal analysis of comic books as media, see: Scott McCloud, Understanding Comics: The Invisible Art (New York: William Morrow/HarperCollins, 1993) and, Martin Barker, Comics: Ideology, Power, and the Critics (Manchester: Manchester University Press, 1989). For a more linguistic and psycholinguistic approach see: Neil Cohn, The Visual Language of Comics: Introduction to the Structure and Cognition of Sequential Images (London: Bloomsbury Academic, 2013).

13. For other forms of narrative illustrations alongside comics, see: Gillian Poulter, Becoming Native in a Foreign Land: Sport, Visual Culture, and Identity in Montreal, 1840-85 (Vancouver: University of British Columbia Press, 2009). In addition, on the development of the comic book industry and its relationship with motorsport, tie-in products, toys and their accessories, see: Jean Williams “"Tri-ang Strong Toys": Lines Brothers and British Motor Sport in the InterWar Period', Sport in History 35, no. 3 (2015): 419-40.

14. Dave Day and Wray Vamplew, 'Sports History Methodology: Old and New', The International Journal of the History of Sport 32, no. 15 (2015): 1718.

15. Wray Vamplew, 'In Praise of Numbers: Quantitative Sports History', The International Journal of the History of Sport 32, no. 15 (2015): 1835-49.

16. Mike Huggins, 'The Visual in Sport History: Approaches, Methodologies and Sources', The International Journal of the History of Sport 32, no. 15 (2015): 1813-30.

17. Groensteen, Bande dessinée, 7 .

18. Pierre Fresnault-Deruelle, Dessins et bulles: la bande dessinée comme moyen d'expression (Paris: Bordas, 1972), 39.

19. Thierry Groensteen, Système de la bande dessinée (Paris: Presses Universitaires de France, 1999), 21.

20. Benoit Peeters, Lire la bande dessinée (Paris: Flammarion, 2002), 122.

21. Roland Barthes, La chambre claire, (Paris: Seuil, 1980); Roland Barthes, L'obvie et l'obtus. Essais critiques III (Paris: Seuil, 1982).

22. Roland Barthes, 'Présentation', Communications 4, no. 1 (1964): 1-3.

23. Editorial, 'Jean Graton nous parle de Michel Vaillant', Tintin, Journal des Jeunes de 7 à 77 ans 770, 5 July (1963): 14-21.

24. 'Jean Graton à propos d'une exposition sur Michel Vaillant', Journal Télévision soir Pays de la Loire, 9 January 1999.

25. Jean Graton, Le 13 est au départ, no. 5, (Bruxelles: Graton Editeurs, 1963), 53.

26. Editorial, 'Jean Graton', 14.

27. André-Paul Duchateau, 'Qui fait votre journal? Aujourd'hui: en piste avec ... Jean Graton', Tintin, Journal des Jeunes de 7 à 77 ans 1082, 24 July (1969): 30.

28. Jean Graton, Michel Vaillant: l'intégrale, vol. 4 (Bruxelles: Le Lombard, 2008), 3.

29. Ibid. 
30. Editorial, 'Jean Graton', 14.

31. Ibid.

32. Alain Lerman, Histoire du journal Tintin (Grenoble: Glénat, 1979), 11.

33. Henri Filippini, Dictionnaire de la bande dessinée (Paris: Bordas, 1989), XVI.

34. Lerman, Histoire, 11.

35. Editorial, 'Jean Graton', 14.

36. Tintin, no. 250, 6 August 1953; Tintin, no. 400, 21 June 1956; Tintin, no. 416, 11 October 1956.

37. Tintin, no. 278, 18 February 1954.

38. Tintin, no. 306, 2 September 1954; Tintin, no. 402, 5 July 1956.

39. Tintin, no. 372, 8 December 1955.

40. Tintin, no. 384, 1 March 1956.

41. Tintin, no. 350, 7 July 1955.

42. Tintin, no. 382, 16 February 1956.

43. Tintin, no. 509, 24 July 1958.

44. Tintin, no. 420, 8 November 1956.

45. Tintin, no. 433, 7 February 1957.

46. Jean Graton, Michel Vaillant: l'intégrale, vol. 1 (Bruxelles: Le Lombard, 2008), 6.

47. Lerman, Histoire, 9.

48. Jean Graton, Km. 357, no. 16 (Bruxelles: Graton Editeurs, 1969), 46.

49. Ibid.

50. Benoît Berthou, 'La Bande dessinée de Fantasy: un genre français?', Contemporary French and Francophone Studies 15, no 2 (2011): 213.

51. Philippe Delisle, Spirou, Tintin et Cie, une littérature catholique? Années 1930 années 1980 (Paris: Karthala, 2010), 13.

52. Editorial, 'Jean Graton', 15.

53. Jeet Heer, 'Barnaby and American Clear Line Cartooning', in Barnaby Volume One, ed. Crockett Johnson, (Seattle: Fantagraphics Books, 2013), 13.

54. Duchateau, 'Qui fait votre journal?', 30-1.

55. Ibid., 31 .

56. The expression Treinte Glorieuses is attributed to Jean Fourastier in his analysis 'Les Trentes Glorieuses, ou la révolution invisible de 1946 à 1973', published in 1979. However, authors such as Bost affirm that it was also a troubling period, both socially and economically speaking, during the so-called Reconstruction period. The repetitive strikes organised by French industrial trade unions and pay gaps between lower and middle classes expressed this protest and disenchantment in May 1968. In François Bost, La Franche: mutations des systèmes productifs (Paris: Sedes/Cne, 2014), 98.

57. Christian Metz, 'Le perçu et le nommé', in Essais sémiotiques (Paris: Klincksieck, 1977), 129-62.

58. Jean-Charles Asselain, Histoire économique de la France. De 1919 à la fin des années 1970 (Paris: Seuil, 1984), 127.

59. Pascal Lefèvre, 'The construction of national and foreign identities in French and Belgian postwar comics (1939-1970)', Comicalités. Études de culture graphique, (2012), http://comicalites.revues.org/875 (accessed 10 March 2017).

60. Graton, 13 est au départ, 11.

61. Panhard gives us a exhaustive list: Peugeot 404, Simca 1000, 1300 and 1500, Citroën Ami 6, Panhard PL 17, Renault 4, and Renault 8. In Jean Panhard, 'Petite histoire del'automobile en France', Culture Technique 19 (1989): 31. 
62. Jean Graton, La trahison de Steve Warson, no. 6 (Bruxelles: Graton Editeurs, 1964), 60.

63. Jean Graton, L’honneur du samourä̈, no. 10 (Bruxelles: Graton Editeurs, 1966), 9-10.

64. Thierry Méot, 'L'indutrie automobile depuis 1950: des mutations à la chaîne', in L'économie française, ed. INSEE (Paris: INSEE, 2009), 113.

65. Joffre Dumazedier, Revolution culturelle du temps libre 1968-1988 (Paris: Meridiens Klincksieck, 1988).

66. Daniel Henri, 'L'Auto', in La France d'un siècle à l'autre (1914-2000), vol. 1, ed. Jean-Pierre Rioux and Jean-François Sirinelli (Paris: Hachette, 1999), 537.

67. One mythical model of Matra of this period symbolises both sporting, fun and innovation elements at an affordable price: the M530 ('la voiture des copains', the friends' car), which was sold between 1967 and 1973 in a total of 9,609 exemplaires, http://matra.com/article/historique-chiffres-cles (accessed 19 June 2016).

68. Jean Graton, Route de nuit, no. 4 (Bruxelles: Graton Editeurs, 1962); Jean Graton, Le retour de Steve Warson, no. 9 (Bruxelles: Graton Editeur, 1965); Jean Graton, Les chevaliers de Königsfeld, no. 12 (Bruxelles: Graton Editeurs, 1967); Jean Graton, Concerto pour pilotes, no. 13 (Bruxelles: Graton Editeurs, 1968); Graton, Km. 357.

69. Jean Graton, Le pilote sans visage, no. 2 (Bruxelles: Graton Editeurs, 1960), 12.

70. Jean Graton, Les casse-cou, no. 7 (Bruxelles: Graton Editeurs, 1964), 24-7 and 46-51.

71. Ibid., 9.

72. Stephen Bayler, Sex, Drink and Fast Cars: The Creation and Consumption of Images (London: Faber \& Faber, 1986).

73. Jean Graton, Le grand défi, no. 1 (Bruxelles: Graton Editeurs, 1959), 23.

74. Ibid.

75. Graton, 13 est au départ.

76. Graton, Honneur du samouraï, 50.

77. Jean Graton, Le cirque infernal, no. 15 (Bruxelles: Graton Editeurs, 1969), 4.

78. Graton, Trahison de Steve Warson, 3.

79. Jean-Louis Loubet, Histoire de l'automobile française (Paris: Seuil, 2001), 369.

80. Graton, Grand défi, 4.

81. Jean Graton, Le circuit de la peur, no. 3 (Bruxelles: Graton Editeurs, 1961), 7.

82. Graton, Pilote sans visage, 42.

83. Graton, Circuit de la peur, 8.

84. Graton, 13 est au départ, 6.

85. Graton, Trahison de Steve Warson, 37-8.

86. Graton, Casse-cou, 22.

87. According to Loubet, this publication sold 300,000 copies at that time, and even 600,000 with the Citroën DS 19 launch in 1955. In Loubet, Histoire, 364.

88. Erwin Panofsky, Meaning in the Visual Arts: Papers in and on Art History (New York: Doubleday, 1955).

89. Rudolf Wittkower, 'Interpretation of Visual Symbols in the Arts', in Allegory and the Migration of Symbols (London: Thames \& Hudson, 1977), 173-87.

90. Graton, Grand défi, 4 and 20.

91. Graton, Trahison de Steve Warson, 61.

92. Jean Graton, Mach 1 pour Steve Warson, no. 14 (Bruxelles: Graton Editeurs, 1968), 34. 
93. Jean Graton, Le $8^{e}$ pilote, no. 8 (Bruxelles: Graton Editeurs, 1965), 4.

94. Jean Graton, Suspense à Indianapolis, no. 11 (Bruxelles: Graton Editeurs, 1966), cover.

95. Graton, Chevaliers de Königsfeld, 64.

96. Graton, Honneur du samourä̈, 44.

97. Graton, Trahison de Steve Warson, 6.

98. Ross Kristin, Aller plus vite, laver plus blanc: la culture française au tournant des années soixante (Paris: Abbeville Press, 1997).

99. Mike McNamee, 'Whose Prometheus? Transhumanism, Biotechnology and the Moral Topography of Sports Medicine', Sport, Ethics and Philosophy 1, no. 2 (2007): 181-94.

100. Hans Lenk, 'Herculean "myth" aspects of athletics', Journal of the Philosophy of Sport 3 (1976): 11-21.

101. David J. Lunt, 'The Heroic Athlete in Ancient Greece', Journal of Sport History 36 , no. 3 (2009): 375-93.

102. Graton, $\mathrm{Km} .357$.

103. Bruno Latour, preface to De l'histoire des transports à l'histoire de la mobilité, ed. Mathieu Flonneau and Vincent Guigueno (Rennes: PUR, 2009).

104. Barthes, Mythologies.

105. Alain Prost, preface to Michel Vaillant: l'intégrale, vol. 1, by Jean Graton (Bruxelles: Le Lombard, 2008).

\section{Acknowledgements}

The authors would like to thank Lois Rose (The Language Center) for her editing, Dave Day for his advice and Graton-Dupuis Publishing for giving permission to reproduce boxes of the series of Michel Vaillant comic books.

\section{Disclosure statement}

No potential conflict of interest was reported by the authors. 